\title{
Using Diels-Alder reactions to synthesize [2]rotaxanes under solvent-free conditions
}

\author{
Chi-Chieh Hsu ${ }^{a}$, Chien-Chen Lai ${ }^{\mathrm{b}}$, Sheng-Hsien Chiu ${ }^{\mathrm{a}, *}$ \\ ${ }^{a}$ Department of Chemistry, National Taiwan University, No. 1, Sec. 4, Roosevelt Road, Taipei 10617, Taiwan, ROC \\ ${ }^{\mathrm{b}}$ Institute of Molecular Biology, National Chung Hsing University and Department of Medical Genetics, China Medical University Hospital, Taichung, Taiwan, ROC
}

\section{A R T I C L E I N F O}

Article history:

Received 17 December 2008

Accepted 22 December 2008

Available online 4 February 2009

\begin{abstract}
A B S T R A C T
Diels-Alder reactions of the terminal alkyne units of $\mathrm{SiO}_{2}$-supported [2]pseudorotaxanes with 1,2,4,5tetrazine derivatives proceed efficiently through solid-to-solid contact to provide both asymmetric and symmetric [2]rotaxanes incorporating either 24- or 25-membered-ring macrocycles.
\end{abstract}

(c) 2009 Elsevier Ltd. All rights reserved.

\section{Introduction}

Several [2]rotaxanes, supermolecular compounds comprising an interlocked macrocycle and a dumbbell-shaped thread component, have been developed as components for molecular electronic devices. ${ }^{1}$ Among the protocols that can be used to synthesize rotaxanes, the 'threading-followed-by-stoppering' approach ${ }^{2}$ is one of the most straightforward; it relies on weak intermolecular interactions to position the threadlike component within the cavity of the macrocycle and then the interlocking of the components of the resulting pseudorotaxane is performed using a suitable stoppering reaction. The formation of pseudorotaxanes from crown ethers and dibenzylammonium (DBA) ions in solution has been studied now for almost 15 years; the application of this binding motif has resulted in many elegant interlocked molecules and functional materials. ${ }^{3}$ The efficiency of rotaxane syntheses from their pseudorotaxane precursors in solution is, however, frequently affected by factors such as the concentration of the mixture, competing solvents, and the formation of interfering byproducts. Because these disturbing influences are less pronounced in the solid state, reactions that can proceed under solvent-free conditions would be ideal for the efficient synthesis of crown ether/DBA ionbased rotaxanes. Because of the paucity of known stoppering reactions that proceed efficiently under the conditions of direct solid-to-solid contact, only a few such syntheses have been reported so far. ${ }^{4}$ Previously, we revealed that the ball-milling of terminal alkynes and 1,2,4,5-tetrazine produces pyridazine rings, which are sufficiently sterically bulky to interlock the small [21]crown-7 $(21 \mathrm{C} 7)^{5}$ macrocycle; using this approach, we synthesized what we

\footnotetext{
* Corresponding author.

E-mail address: shchiu@ntu.edu.tw (S.-H. Chiu).
}

believe is the smallest [2]rotaxane ever prepared. ${ }^{6}$ To apply this synthetic method to the construction of functional interlocked molecules, it was necessary for us to broaden the reaction's scope so that we could interlock macrocycles more sizable than 21C7. Herein, we report a modified set of reaction conditions for this solvent-free stoppering approach, one that allows the efficient interlocking of 24- and 25-membered-ring macrocycles in the form of [2]rotaxanes.

\section{Results and discussion}

Previously, we demonstrated that Diels-Alder reactions between terminal alkynes and 1,2,4,5-tetrazine proceed efficiently under solid-to-solid ball-milling conditions. ${ }^{6}$

Based on the knowledge that macrocycle 1 can complex DBA ions tightly in low-polarity solvents, ${ }^{7}$ for its use as the threadlike component we synthesized the salt $2-\mathrm{H} \cdot \mathrm{PF}_{6}$, which contains a p-tert-butyl phenyl terminus (i.e., a stopper for $\mathbf{1}$ ) and a terminal alkyne unit, from the amine $\mathbf{3}$ and the aldehyde $\mathbf{4}$ through sequential condensation, reduction, and ion exchange processes (Scheme 1). We calculated the association constants for the interactions between macrocycle 1 and thread $2-\mathrm{H} \cdot \mathrm{PF}_{6}$ in $\mathrm{CD}_{3} \mathrm{CN}$ and $\mathrm{CD}_{3} \mathrm{NO}_{2}$ to be 350 and $8600 \mathrm{M}^{-1}$, respectively, based on a ${ }^{1} \mathrm{H}$ NMR spectroscopy-based single-point method. ${ }^{8}$ Thus, we expected that concentrating an equimolar solution of the macrocycle $\mathbf{1}$ and the threadlike salt $\mathbf{2}-\mathrm{H} \cdot \mathrm{PF}_{6}$ would result in a solid containing predominantly the [2]pseudorotaxane complex $\left[(\mathbf{1} \supset \mathbf{2}-\mathrm{H}) \cdot \mathrm{PF}_{6}\right] .^{9}$

Concentrating an equimolar mixture of the macrocycle $\mathbf{1}$ and the threadlike salt $2-\mathrm{H} \cdot \mathrm{PF}_{6}$ in $\mathrm{CH}_{3} \mathrm{NO}_{2}$ provided a sticky liquid rather than a solid; therefore, we added silica gel to the solution and then evaporated the organic solvent under reduced pressure. Because macrocycle 1 forms a [2]pseudorotaxane with DBA in lowpolarity solvents, and because unsubstituted pyridazine rings are 


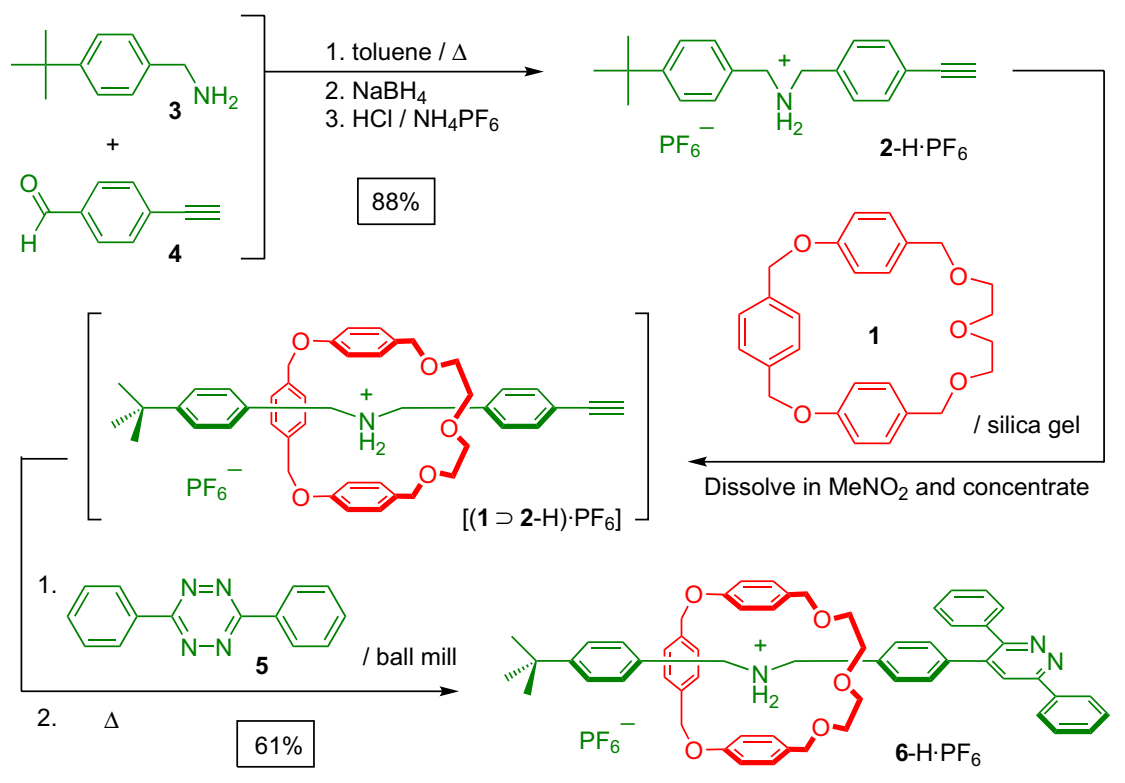

Scheme 1.

smaller than a benzene ring, we suspected that the pyridazine unit generated from the reaction of a terminal alkyne with 1,2,4,5-tetrazine would not be a true stopper for interlocking the macrocycle 1 within a [2]rotaxane. Thus, we applied 3,6-diphenyl-1,2,4,5-tetrazine (5) to the reaction with the expectation that the steric bulk of the resulting diphenylpyridazine would be sufficient to prevent dethreading of macrocycle $\mathbf{1}$ from the resulting [2]rotaxane. From ${ }^{1} \mathrm{H}$ NMR spectroscopic analyses, the ball-milling of an equimolar mixture of the $\mathrm{SiO}_{2}$-supported [2]pseudorotaxane $\left[(\mathbf{1} \supset \mathbf{2}-\mathrm{H}) \cdot \mathrm{PF}_{6}\right]$ and the solid diphenyltetrazine $\mathbf{5}$ for up to $12 \mathrm{~h}$ produced no detectable signals for the desired [2]rotaxane. Because the grinding of 1,2,4,5-tetrazine with the same $\mathrm{SiO}_{2}$-supported [2]pseudorotaxane $\left[(\mathbf{1} \supset \mathbf{2}-\mathrm{H}) \cdot \mathrm{PF}_{6}\right]$ produced a reasonable amount of the corresponding pyridazine-terminated dumbbell component within $9 \mathrm{~h}$ under the same ball-milling conditions, it appeared that the problem in our [2]rotaxane synthesis was the relatively low reactivity of 3,6diphenyl-1,2,4,5-tetrazine. Relative to 1,2,4,5-tetrazine, which sublimed readily at high temperature to afford a low yield of our 'smallest [2]rotaxane' synthesized under thermal conditions, ${ }^{5}$ 3,6diphenyl-1,2,4,5-tetrazine is less volatile; therefore, we suspected that heating a well-ground solid mixture of the $\mathrm{SiO}_{2}$-supported [2]pseudorotaxane $\left[(\mathbf{1} \supset \mathbf{2}-\mathrm{H}) \cdot \mathrm{PF}_{6}\right]$ and the diphenyltetrazine $\mathbf{5}$ at high temperature would allow the stoppering reaction to proceed efficiently under the solid-to-solid contact. Thus, we ground the $\mathrm{SiO}_{2}$-supported [2]pseudorotaxane $\left[(\mathbf{1} \supset \mathbf{2}-\mathrm{H}) \cdot \mathrm{PF}_{6}\right]$ with the diphenyltetrazine $\mathbf{5}$ for $1 \mathrm{~h}$ and then heated the mixture at $373 \mathrm{~K}$ under atmosphere pressure. ${ }^{10}$ To monitor the progress of the reaction, at various time intervals we dissolved a portion of the solid reaction mixture in $\mathrm{CD}_{3} \mathrm{CN}$, filtered off the $\mathrm{SiO}_{2}$, and then recorded the ${ }^{1} \mathrm{H}$ NMR spectrum of the filtrate. Over time, we observed a new set of signals appeared with increasing intensity (Fig. 1). After heating at $373 \mathrm{~K}$ for 3 days, these signals predominated the spectrum (Fig. 1d); thus, we subjected the mixture to column chromatography $\left(\mathrm{SiO}_{2}: \mathrm{MeOH} / \mathrm{CH}_{2} \mathrm{Cl}_{2}, 2: 98\right)$ and isolated the [2] rotaxane $\mathbf{6}-\mathrm{H} \cdot \mathrm{PF}_{6}$ in $61 \%$ yield. Similar reactions performed in solution did not proceed as efficiently as it did in the solid state; indeed, heating an equimolar $(20 \mathrm{mM})$ mixture of the macrocycle $\mathbf{1}$, the threadlike salt $\mathbf{2}-\mathrm{H} \cdot \mathrm{PF}_{6}$, and the diphenyltetrazine $\mathbf{5}$ in $\mathrm{CD}_{3} \mathrm{CN}$ (at $343 \mathrm{~K}$ ) or $\mathrm{CD}_{3} \mathrm{NO}_{2}$ (at $353 \mathrm{~K}$ ) gave a complicated set of products after 3 days.

To demonstrate that the same synthetic method could be applied to synthesize a symmetric [2]rotaxane, we synthesized the diyne $\mathbf{1 0}-\mathrm{H} \cdot \mathrm{PF}_{6}$ in three steps from the amine 7 (Scheme 2). Bocprotection of $\mathbf{7}$ followed by Sonogashira coupling of the resulting dibromide $\mathbf{8}$ with trimethylsilylacetylene afforded the diyne $\mathbf{9}$. Removal of the silyl and Boc protecting groups of $\mathbf{9}$ under basic and acidic conditions, respectively, with subsequent ion exchange and column chromatography, gave the desired threadlike salt $\mathbf{1 0}-\mathrm{H} \cdot \mathrm{PF}_{6}$. Concentrating a mixture of the macrocycle $\mathbf{1}$, the threadlike diyne 10- $\mathrm{H} \cdot \mathrm{PF}_{6}$, and $\mathrm{SiO}_{2}$ in $\mathrm{CH}_{3} \mathrm{NO}_{2}$ gave a solid, which we assumed

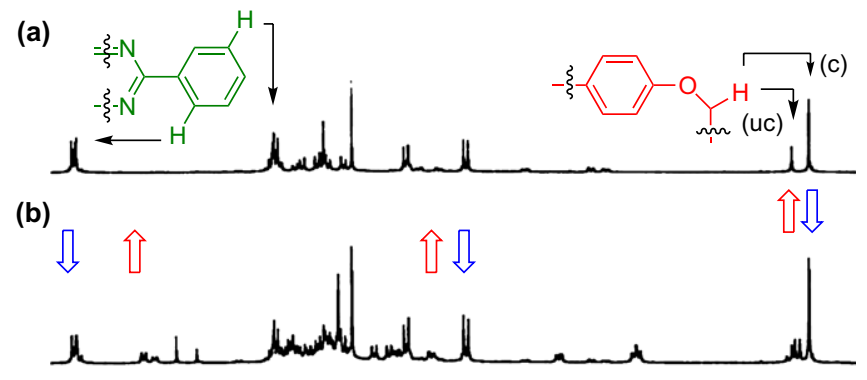

(c)

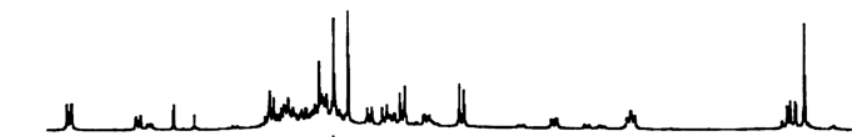

(d)

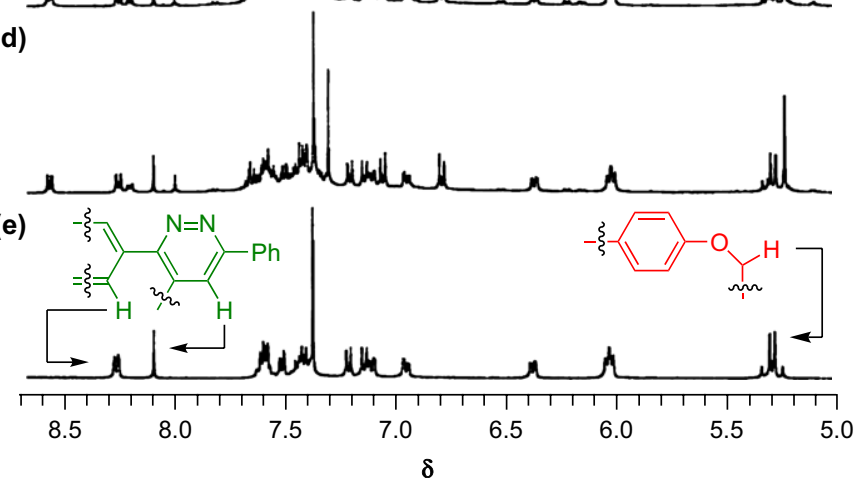

Figure 1. Partial ${ }^{1} \mathrm{H}$ NMR spectra $\left(400 \mathrm{MHz}, \mathrm{CD}_{3} \mathrm{CN}, 298 \mathrm{~K}\right)$ revealing the formation of the [2] rotaxane $6-\mathrm{H} \cdot \mathrm{PF}_{6}$ during the heating of a ball-milled $(1 \mathrm{~h})$ solid mixture of the $\mathrm{SiO}_{2}$-supported [2]pseudorotaxane $[\mathbf{1} \supset \mathbf{2}-\mathrm{H}]\left[\mathrm{PF}_{6}\right]$ and the diphenlytetrazine $\mathbf{5}$ for (a) 0 , (b) 24 , (c) 48 , and (d) $72 \mathrm{~h}$; (e) spectrum of isolated $\mathbf{6}-\mathrm{H} \cdot \mathrm{PF}_{6}$. 


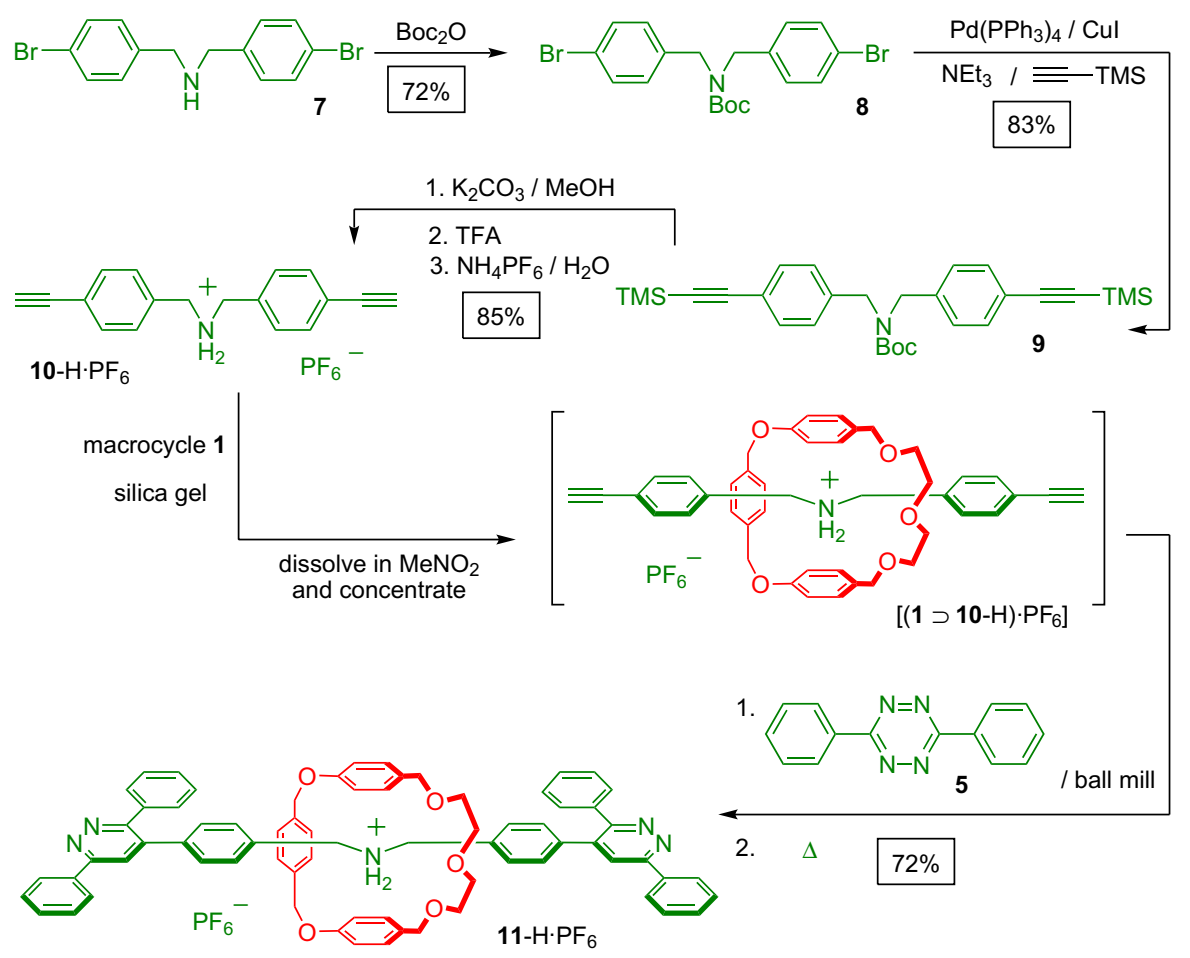

Scheme 2.

contained predominantly the [2]pseudorotaxane $\left[(\mathbf{1} \supset \mathbf{1 0}-\mathrm{H}) \cdot \mathrm{PF}_{6}\right]$. Ball-milling of this solid in the presence of the diphenyltetrazine $\mathbf{5}$ (molar ratio, 1:2) for $1 \mathrm{~h}$ and then heating the resulting solid mixture at $373 \mathrm{~K}$ for 3 days gave the desired symmetrical [2]rotaxane 11- $\mathrm{H} \cdot \mathrm{PF}_{6}$, which we isolated in $72 \%$ yield after column chromatography $\left(\mathrm{SiO}_{2}\right.$ : $\left.\mathrm{MeOH} / \mathrm{CH}_{2} \mathrm{Cl}_{2}, 2: 98\right)$. Relative to the ${ }^{1} \mathrm{H}$ NMR spectra of 1 and $10-\mathrm{H} \cdot \mathrm{PF}_{6}$ (Fig. 2), the significant upfield shift for the signal of the methylene proton adjacent to the $\mathrm{NH}_{2}^{+}$center in the [2] rotaxane 11-H.PF 6 and the separation of the originally overlapping signals (at $\delta 3.46$ ) for the protons of the ethylene glycol unit into separate signals at $\delta 3.09$ and 3.52, confirmed that $[\mathrm{N}-\mathrm{H} \cdots$ $\mathrm{O}]$ and $[\mathrm{C}-\mathrm{H} \cdots \pi]$ hydrogen bonds were important noncovalent interactions stabilizing the recognition of the macrocycle $\mathbf{1}$ by the dumbbell-shaped salt. Thus, both asymmetric and symmetric [2]rotaxanes featuring the 25-membered-ring macrocycle 1 were efficiently synthesized using the same solvent-free Diels-Alder reaction, i.e., by simply heating a well-ground mixture of the $\mathrm{SiO}_{2}$-supported alkyne-terminated [2]pseudorotaxanes and 3,6diphenyl-1,2,4,5-tetrazine at $373 \mathrm{~K}$ for a few days.

To prove the generality of this synthetic method, we mixed the threadlike salts $\mathbf{2}-\mathrm{H} \cdot \mathrm{PF}_{6}$ and $\mathbf{1 0}-\mathrm{H} \cdot \mathrm{PF}_{6}$ individually with $\mathrm{SiO}_{2}$ and dibenzo[24]crown-8 (DB24C8) in solution and concentrated the mixtures to produce the corresponding solids coating with the

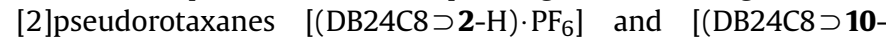
$\mathrm{H}) \cdot \mathrm{PF}_{6}$ ], respectively (Scheme 3 ). Grinding these solids individually with the diphenyltetrazine $\mathbf{5}$ for $1 \mathrm{~h}$ and then heating the resulting solid mixtures at $373 \mathrm{~K}$ for 3 days afforded the desired asymmetric and symmetric [2]rotaxanes $\mathbf{1 2}-\mathrm{H} \cdot \mathrm{PF}_{6}(73 \%)$ and $\mathbf{1 3}-\mathrm{H} \cdot \mathrm{PF}_{6}(72 \%)$, respectively, after column chromatography $\left(\mathrm{SiO}_{2}: \mathrm{MeOH} / \mathrm{CH}_{2} \mathrm{Cl}_{2}\right.$, 2:98). Figure 3 reveals the gradual formation of the [2]rotaxane

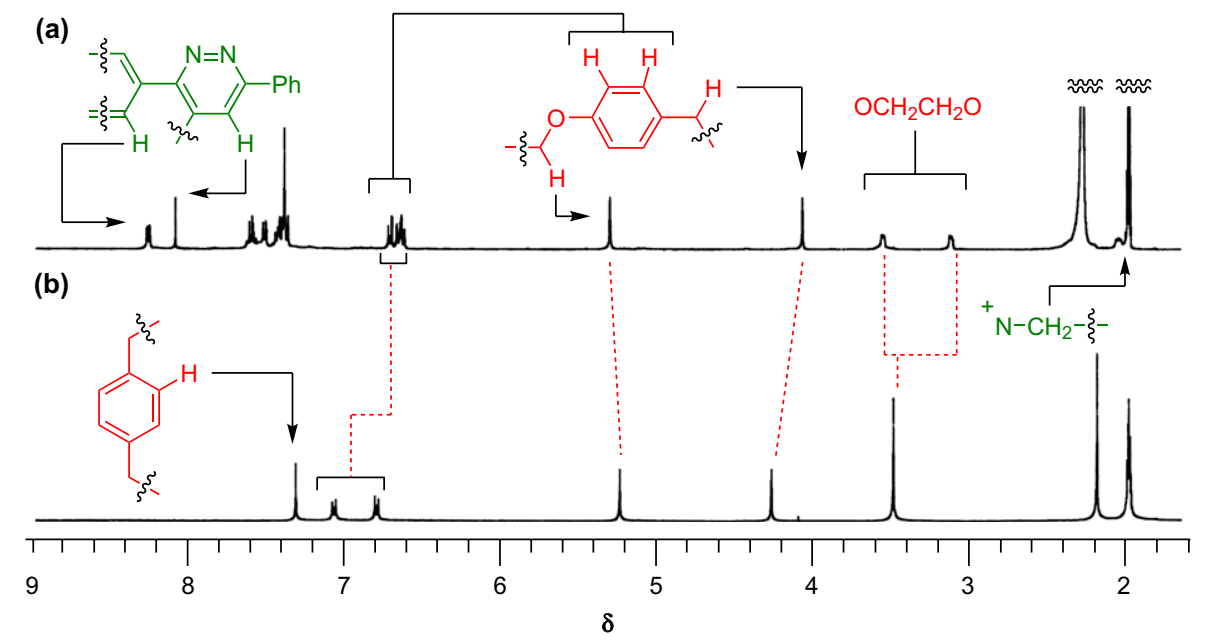

Figure 2. ${ }^{1} \mathrm{H}$ NMR spectra $\left(400 \mathrm{MHz}, \mathrm{CD}_{3} \mathrm{CN}, 298 \mathrm{~K}\right)$ of (a) the symmetric [2]rotaxane $\mathbf{1 1}-\mathrm{H} \cdot \mathrm{PF}_{6}$ and (b) the macrocycle $\mathbf{1}$. 


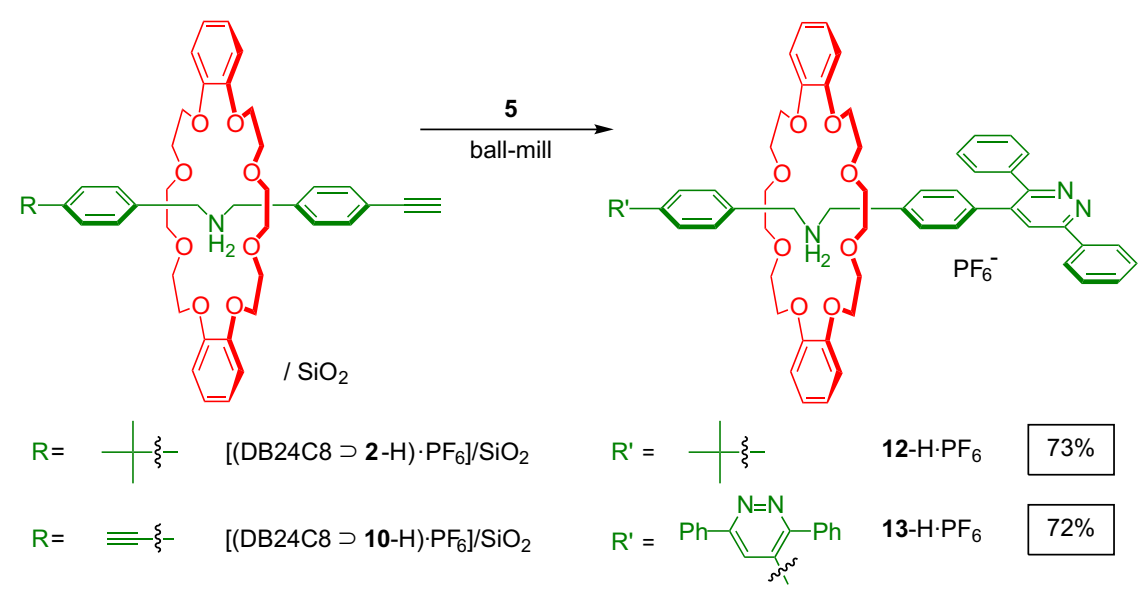

Scheme 3.

(a)

(b)

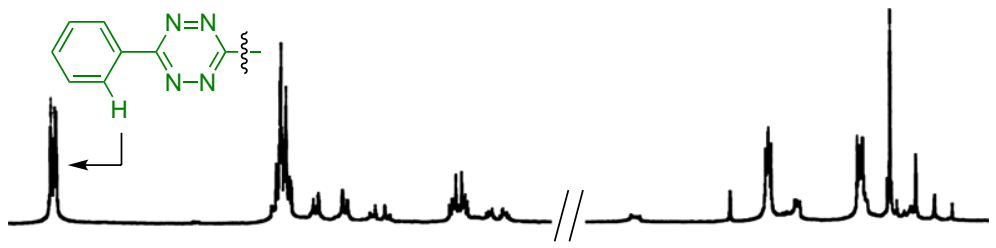

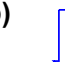

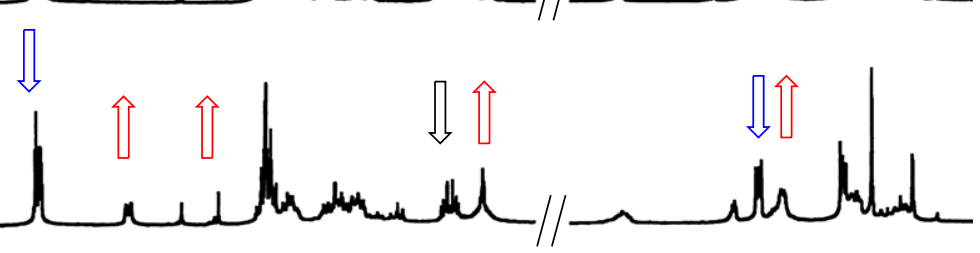

(c)

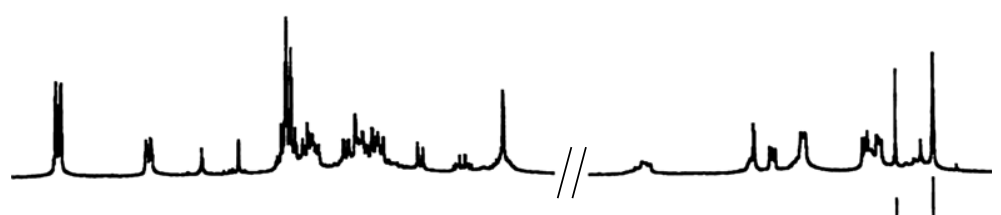

(d)

(e)

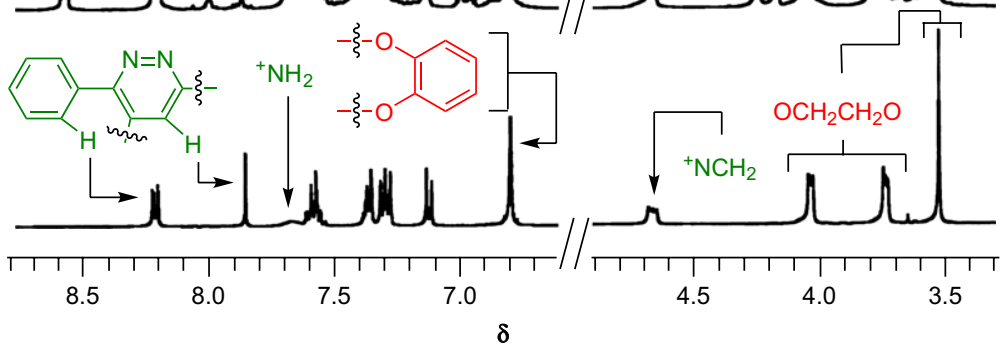

Figure 3. Partial ${ }^{1} \mathrm{H}$ NMR spectra ( $400 \mathrm{MHz}, \mathrm{CD}_{3} \mathrm{CN}, 298 \mathrm{~K}$ ) displaying the formation of the [2]rotaxane $13-\mathrm{H}^{-} \mathrm{PF}_{6}$ during the heating of a ball-milled $(1 \mathrm{~h})$ solid mixture of the SiO${ }_{2}-$ supported [2]pseudorotaxane [DB24C8 $\supset \mathbf{1 0}-\mathrm{H}]\left[\mathrm{PF}_{6}\right]$ and the diphenyltetrazine 5 for (a) 0 , (b) 24, (c) 48, and (d) $72 \mathrm{~h}$; (e) spectrum of isolated 13-H. $\mathrm{PF}_{6}$.

13-H $\cdot \mathrm{PF}_{6}$ during this 'grinding-followed-by-heating' process. Thus, the efficiency of this stoppering method was retained when changing the nature of the macrocyclic component.

\section{Conclusion}

We have demonstrated that the Diels-Alder reactions of the terminal alkyne units of $\mathrm{SiO}_{2}$-supported [2]pseudorotaxanes with 1,2,4,5-tetrazine derivatives proceed efficiently through solid-to- solid contact to provide both asymmetric and symmetric [2]rotaxanes incorporating either of the macrocycles 1 or DB24C8. We suspect that the convenience and environmentally benign nature of this synthetic method will be helpful for the construction of other complex interlocked molecules exhibiting various functions. The presence of the pyridazine termini of these [2]rotaxanes provides the possibility of using them as building blocks for assembling complicated molecular architectures in the presence of suitable metal ions; such studies are under investigation in our laboratory. 


\section{Experimental}

\subsection{General}

All glassware, stirrer bars, syringes, and needles were either oven- or flame-dried prior to use. All reagents, unless otherwise indicated, were obtained from commercial sources. Anhydrous $\mathrm{CH}_{2} \mathrm{Cl}_{2}$ and $\mathrm{MeCN}$ were obtained through distillation from $\mathrm{CaH}_{2}$ under $\mathrm{N}_{2}$. Anhydrous THF was obtained through distillation from $\mathrm{Na} / \mathrm{Ph}_{2} \mathrm{CO}$ under $\mathrm{N}_{2}$. Reactions were conducted under $\mathrm{N}_{2}$ or $\mathrm{Ar}$ atmospheres. Thin layer chromatography (TLC) was performed on Merck 0.25-mm silica gel (Merck Art. 5715). Column chromatography was undertaken over Kieselgel 60 (Merck, 70-230 mesh). Melting points are uncorrected. Ball-milling was performed using a Retsch MM 200 swing-mill, containing two 5-mL stainless-steel cells and two stainless-steel balls (diameter: $7 \mathrm{~mm}$ ); the mill was operated at a frequency of $22.5 \mathrm{~Hz}$ at room temperature. In NMR spectra, the deuterated solvent was used as the lock; the role of the internal standard was played by either TMS or the solvent's residual protons. Chemical shifts are reported in parts per million (ppm). Multiplicities are given as s (singlet), d (doublet), $\mathrm{t}$ (triplet), $\mathrm{q}$ (quartet), m (mutiplet), and br (broad).

\section{2. [2]Rotaxane 6-H $\cdot \mathrm{PF}_{6}$}

The organic solvent was evaporated under reduced pressure from a mixture of macrocycle $\mathbf{1}(100 \mathrm{mg}, 0.24 \mathrm{mmol})$, the alkyne 2$\mathrm{H} \cdot \mathrm{PF}_{6}(100 \mathrm{mg}, 0.24 \mathrm{mmol})$, and silica gel $(200 \mathrm{mg})$ in $\mathrm{CH}_{3} \mathrm{NO}_{2}$ $(10 \mathrm{~mL})$ to afford a solid mixture, which was then mixed with 3,6diphenyl-1,2,4,5-tetrazine (61 $\mathrm{mg}, 0.26 \mathrm{mmol}$ ) and ball-milled at room temperature for $1 \mathrm{~h}$. The solid mixture was transferred to a $5 \mathrm{~mL}$ flask, heated to $100{ }^{\circ} \mathrm{C}$ for 3 days, and then purified chromatographically $\left(\mathrm{SiO}_{2}: \mathrm{MeOH} / \mathrm{CH}_{2} \mathrm{Cl}_{2}, 2: 98\right)$ to afford the [2]rotaxane $\mathbf{6}-\mathrm{H} \cdot \mathrm{PF}_{6}$ as a white solid $(153 \mathrm{mg}, 61 \%) . \mathrm{Mp}=173-174{ }^{\circ} \mathrm{C} ;{ }^{1} \mathrm{H}$ $\operatorname{NMR}\left(400 \mathrm{MHz}, \mathrm{CD}_{3} \mathrm{CN}\right): \delta=1.05$ (t, $\left.J=7 \mathrm{~Hz}, 2 \mathrm{H}\right), 1.41(\mathrm{~s}, 9 \mathrm{H}), 2.99(\mathrm{t}$, $J=6 \mathrm{~Hz}, 2 \mathrm{H}), 3.02-3.09(\mathrm{~m}, 2 \mathrm{H}), 3.26-3.31(\mathrm{~m}, 2 \mathrm{H}), 3.55-3.60(\mathrm{~m}$, $4 \mathrm{H}), 3.80$ (d, $J=9 \mathrm{~Hz}, 2 \mathrm{H}), 4.28$ (d, $J=9 \mathrm{~Hz}, 2 \mathrm{H}), 5.27$ (dd, $J=25,15 \mathrm{~Hz}$, $4 \mathrm{H}), 5.97-6.02(\mathrm{~m}, 4 \mathrm{H}), 6.35$ (dd, $J=8,2 \mathrm{~Hz}, 2 \mathrm{H}), 6.95(\mathrm{dd}, J=9,3 \mathrm{~Hz}$, 2H), 7.10-7.21 (m, 6H), 7.37 (s, 4H), 7.39-7.54 (m, 7H), 7.55-7.63 (m, $5 \mathrm{H}), 8.10(\mathrm{~s}, 1 \mathrm{H}), 8.27$ (dd, $J=7,2 \mathrm{~Hz}, 2 \mathrm{H}) ;{ }^{13} \mathrm{C}$ NMR $(100 \mathrm{MHz}$, $\left.\mathrm{CD}_{3} \mathrm{CN}\right): \delta=31.5,35.5,49.1,52.5,68.2,69.8,71.3,74.4,115.0,125.6$, $126.6,126.8,127.2,127.9,128.0,129.0,129.2,129.4,129.9,129.9$, 130.7, 131.0, 131.3, 131.7, 132.2, 132.9, 137.0, 137.0, 138.2, 138.3, 139.8, 154.1, 158.0, 158.7; HRMS (ESI): $m / z$ calcd for $[6-\mathrm{H}]^{+}\left(\mathrm{C}_{60} \mathrm{H}_{62} \mathrm{~N}_{3} \mathrm{O}_{5}\right)$ : 904.4684; found: 904.4689 .

\section{3. tert-Butyl bis(4-bromobenzyl)carbamate (8)}

Di-tert-butyl dicarbonate $(570 \mathrm{mg}, 2.6 \mathrm{mmol}$ ) and triethylamine (390 $\mathrm{mg}, 3.9 \mathrm{mmol}$ ) were added to a solution of the dibromide 7 $(920 \mathrm{mg}, 2.59 \mathrm{mmol})$ in $\mathrm{MeOH}(15 \mathrm{~mL})$ and then the mixture was stirred at room temperature for $24 \mathrm{~h}$. The organic solvent was evaporated under reduced pressure and the crude product purified chromatographically $\left(\mathrm{SiO}_{2}: \mathrm{CH}_{2} \mathrm{Cl}_{2} /\right.$ hexane, $\left.1: 1\right)$ to yield the Bocprotected dibromide 8 as a yellow liquid $(0.84 \mathrm{~g}, 72 \%) .{ }^{1} \mathrm{H}$ NMR $\left(400 \mathrm{MHz}, \mathrm{CDCl}_{3}\right): \delta=1.47$ (s, 9H), 4.24 (br, 2H), 4.33 (br, 2H), 6.987.10 (br, $4 \mathrm{H}), 7.43$ (d, $J=8 \mathrm{~Hz}, 4 \mathrm{H}) ;{ }^{13} \mathrm{C}$ NMR (100 MHz, $\left.\mathrm{CDCl}_{3}\right)$ : $\delta=28.4,48.7,49.0,80.4,121.0,128.8,129.4,131.5,136.6,155.5$; HRMS (ESI): $\mathrm{m} / \mathrm{z}$ calcd for $\left(\mathrm{C}_{19} \mathrm{H}_{21} \mathrm{Br}_{2} \mathrm{NO}_{2}\right)[\mathrm{M}+\mathrm{Na}]$ : 475.98367; found: 475.98367.

\section{4. tert-Butyl bis\{4-[(trimethylsilyl)ethynyl]- benzyl carbamate $(9)$}

Tetrakis(triphenylphosphine)palladium(0)(101 mg, $0.09 \mathrm{mmol})$, copper iodide $(16.7 \mathrm{mg}, 0.09 \mathrm{mmol})$, and trimethylsilylacetylene
(860 $\mathrm{mg}, 8.8 \mathrm{mmol}$ ) were added to a degassed solution of the dibromide $8(1.0 \mathrm{~g}, 2.2 \mathrm{mmol})$ in triethylamine $(15 \mathrm{~mL})$ and then the mixture was heated at $40{ }^{\circ} \mathrm{C}$ for $12 \mathrm{~h}$. After cooling to room temperature, the solution was partitioned between $\mathrm{CH}_{2} \mathrm{Cl}_{2}(10 \mathrm{~mL})$ and $\mathrm{H}_{2} \mathrm{O}(10 \mathrm{~mL})$, the aqueous phase was extracted with $\mathrm{CH}_{2} \mathrm{Cl}_{2}$ $(2 \times 10 \mathrm{~mL})$, and the combined organic phases were dried $\left(\mathrm{MgSO}_{4}\right)$, concentrated, and purified chromatographically $\left(\mathrm{SiO}_{2}: \mathrm{CH}_{2} \mathrm{Cl}_{2} /\right.$ hexane, $1: 3$ ) to afford the carbamate $\mathbf{9}$ as a yellow liquid ( $893 \mathrm{mg}, 83 \%$ ). ${ }^{1} \mathrm{H} \mathrm{NMR}\left(400 \mathrm{MHz}, \mathrm{CDCl}_{3}\right): \delta=0.24(\mathrm{~s}, 18 \mathrm{H}), 1.44(\mathrm{~s}, 9 \mathrm{H}), 4.24(\mathrm{br}, 2 \mathrm{H})$, 4.36 (br, 2H), 7.00-7.18 (br, 4H), 7.39 (d, $J=8 \mathrm{~Hz}, 4 \mathrm{H}) ;{ }^{13} \mathrm{C}$ NMR $\left(100 \mathrm{MHz}, \mathrm{CDCl}_{3}\right): \delta=0.4,28.6,49.4,80.1,93.9,104.6,121.7,126.6$, 127.3, 131.6, 137.7, 155.0; HRMS (ESI): $\mathrm{m} / z$ calcd for $\left(\mathrm{C}_{29} \mathrm{H}_{39} \mathrm{NO}_{2} \mathrm{Si}_{2}\right)$ [M+Na]: 512.2417; found: 512.2417.

\subsection{Ammonium salt $10-H \cdot P_{6}$}

$\mathrm{K}_{2} \mathrm{CO}_{3}(1 \mathrm{~g}, 7.2 \mathrm{mmol})$ was added to a solution of the carbamate $9(890 \mathrm{mg}, 1.8 \mathrm{mmol})$ in $\mathrm{MeOH}(20 \mathrm{~mL})$. The mixture was stirred at room temperature for $30 \mathrm{~min}$ and partitioned between $\mathrm{CH}_{2} \mathrm{Cl}_{2}$ $(20 \mathrm{~mL})$ and $\mathrm{H}_{2} \mathrm{O}(20 \mathrm{~mL})$. The aqueous phase was washed with $\mathrm{CH}_{2} \mathrm{Cl}_{2}(2 \times 20 \mathrm{~mL})$ and then the combined organic phases were concentrated to give a yellow liquid, which was dissolved in a mixture of $\mathrm{MeOH}(15 \mathrm{~mL})$ and trifluoroacetic acid $(5 \mathrm{~mL})$ and stirred at room temperature for $12 \mathrm{~h}$. Saturated aqueous $\mathrm{NH}_{4} \mathrm{PF}_{6}$ solution $(30 \mathrm{~mL})$ was added to the mixture and then the organic solvent was evaporated. The precipitate was filtered off and washed with $\mathrm{H}_{2} \mathrm{O}$ to afford the ammonium salt $\mathbf{1 0}-\mathrm{H} \cdot \mathrm{PF}_{6}$ as a white solid (610 mg, 85\%). $\mathrm{Mp}=210-211^{\circ} \mathrm{C} ;{ }^{1} \mathrm{H}$ NMR (400 MHz, $\mathrm{CD}_{3} \mathrm{CN}$ ): $\delta=3.50(\mathrm{~s}, 2 \mathrm{H}), 4.23(\mathrm{~s}, 4 \mathrm{H}), 7.44(\mathrm{dd}, J=8 \mathrm{~Hz}, 4 \mathrm{H}), 7.56(\mathrm{~d}, J=8 \mathrm{~Hz}$, $4 \mathrm{H}) ;{ }^{13} \mathrm{C}$ NMR $\left(100 \mathrm{MHz}, \mathrm{CD}_{3} \mathrm{CN}\right): \delta=51.9,80.3,83.1,124.2,131.2$, 131.7, 133.2; HRMS (ESI): $m / z$ calcd for $[\mathbf{1 0}-\mathrm{H}]^{+}\left(\mathrm{C}_{18} \mathrm{H}_{16} \mathrm{~N}\right): 246.1277$; found: 246.1283 .

\section{6. [2]Rotaxane $11-\mathrm{H} \cdot \mathrm{PF}_{6}$}

After evaporating (under reduced pressure) the solvent from a mixture of the macrocycle $\mathbf{1}(108 \mathrm{mg}, 0.25 \mathrm{mmol})$, the dialkyne 10- $\mathrm{H} \cdot \mathrm{PF}_{6}\left(100 \mathrm{mg}, 0.25 \mathrm{mmol}\right.$ ), and silica gel $(208 \mathrm{mg})$ in $\mathrm{CH}_{3} \mathrm{NO}_{2}$ $(10 \mathrm{~mL})$, the solid obtained was mixed with 3,6-diphenyl-1,2,4,5tetrazine $(132 \mathrm{mg}, 0.56 \mathrm{mmol}$ ) and ball-milled at room temperature for $1 \mathrm{~h}$. The solid mixture was transferred to a $5 \mathrm{~mL}$ flask, heated at $100{ }^{\circ} \mathrm{C}$ for 3 days, and then purified chromatographically $\left(\mathrm{SiO}_{2}: \mathrm{MeOH} / \mathrm{CH}_{2} \mathrm{Cl}_{2}, 2: 98\right)$ to afford the [2] rotaxane $\mathbf{1 1}-\mathrm{H} \cdot \mathrm{PF}_{6}$ as a yellow solid (210 mg, 72\%). $\mathrm{Mp}=195-196{ }^{\circ} \mathrm{C} ;{ }^{1} \mathrm{H}$ NMR $(400 \mathrm{MHz}$, $\left.\mathrm{CD}_{3} \mathrm{CN}\right): \delta=2.01(\mathrm{t}, J=7 \mathrm{~Hz}, 4 \mathrm{H}), 3.06-3.12(\mathrm{~m}, 4 \mathrm{H}), 3.50-3.56(\mathrm{~m}$, $4 \mathrm{H}), 4.05(\mathrm{~s}, 4 \mathrm{H}), 5.29(\mathrm{~s}, 4 \mathrm{H}), 6.60-6.73(\mathrm{~m}, 12 \mathrm{H}), 7.37-7.47(\mathrm{~m}$, $16 \mathrm{H}), 7.49-7.64(\mathrm{~m}, 10 \mathrm{H}), 8.10(\mathrm{~s}, 2 \mathrm{H}), 8.28(\mathrm{dd}, J=7,2 \mathrm{~Hz}, 4 \mathrm{H}) ;{ }^{13} \mathrm{C}$ NMR $\left(100 \mathrm{MHz}, \mathrm{CD}_{3} \mathrm{CN}\right): \delta=51.1,68.2,69.9,71.2,74.4,116.7,125.8$, 127.9, 128.0, 129.1, 129.1, 129.2, 129.5, 129.9, 130.4, 130.7, 131.0, 131.6, 132.0, 136.9, 138.1, 138.2, 138.4, 139.5, 158.1, 158.6, 159.3; HRMS (ESI): $m / z$ calcd for $[11-\mathrm{H}]^{+}\left(\mathrm{C}_{72} \mathrm{H}_{64} \mathrm{~N}_{5} \mathrm{O}_{5}\right)$ : 1078.4902; found: 1078.4907 .

\section{7. [2]Rotaxane $12-H \cdot P_{6}$}

After evaporating (under reduced pressure) the solvent from a mixture of DB24C8 (390 mg, $0.3 \mathrm{mmol}$ ), the alkyne $2-\mathrm{H} \cdot \mathrm{PF}_{6}$ (300 mg, $0.24 \mathrm{mmol})$, and silica gel $(690 \mathrm{mg})$ in $\mathrm{CH}_{3} \mathrm{NO}_{2}(10 \mathrm{~mL})$, the solid mixture obtained was mixed with 3,6-diphenyl-1,2,4,5tetrazine ( $180 \mathrm{mg}, 0.78 \mathrm{mmol}$ ), ball-milled at room temperature for $1 \mathrm{~h}$, transferred to a $5 \mathrm{~mL}$ flask, and heated at $100{ }^{\circ} \mathrm{C}$ for 3 days. After cooling to room temperature, the resulting solid mixture was purified chromatographically $\left(\mathrm{SiO}_{2}: \mathrm{MeOH} / \mathrm{CH}_{2} \mathrm{Cl}_{2}, 2: 98\right)$ to afford the [2] rotaxane $12-\mathrm{H} \cdot \mathrm{PF}_{6}$ as a white solid ( $\left.560 \mathrm{mg}, 73 \%\right) . \mathrm{Mp}=124-$ $125{ }^{\circ} \mathrm{C} ;{ }^{1} \mathrm{H}$ NMR $\left(400 \mathrm{MHz}, \mathrm{CD}_{3} \mathrm{CN}\right): \delta=1.23(\mathrm{~s}, 9 \mathrm{H}), 3.42-3.57(\mathrm{~m}$, $8 \mathrm{H}), 3.63-3.80(\mathrm{~m}, 8 \mathrm{H}), 3.98-4.06(\mathrm{~m}, 8 \mathrm{H}), 4.54(\mathrm{t}, J=6 \mathrm{~Hz}, 2 \mathrm{H}), 4.74$ 
(t, $J=6 \mathrm{~Hz}, 2 \mathrm{H}), 6.78-6.84(\mathrm{~m}, 8 \mathrm{H}), 7.13$ (dd, $J=6,2 \mathrm{~Hz}, 2 \mathrm{H}), 7.19$ (dd, $J=8,4 \mathrm{~Hz}, 4 \mathrm{H}), 7.22-7.40(\mathrm{~m}, 7 \mathrm{H}), 7.52-7.63(\mathrm{~m}, 5 \mathrm{H}), 7.86(\mathrm{~s}, 1 \mathrm{H})$, 8.23 (dd, $J=8,2 \mathrm{~Hz}, 2 \mathrm{H}$ ); ${ }^{13} \mathrm{C}$ NMR $\left(100 \mathrm{MHz}, \mathrm{CD}_{3} \mathrm{CN}\right): \delta=31.3,35.0$, 52.4, 53.0, 68.5, 70.6, 71.0, 112.7, 121.4, 125.1, 125.5, 127.2, 128.3, 128.7, 129.2, 129.4, 129.5, 129.9, 130.2, 133.0, 136.2, 137.3, 137.4, 139.6, 147.4, 152.1, 157.5, 158.2 (two signals are missing, possibly because of signal overlap); HRMS (ESI): $m / z$ calcd for $[12-\mathrm{H}]^{+}$ $\left(\mathrm{C}_{58} \mathrm{H}_{66} \mathrm{~N}_{3} \mathrm{O}_{8}\right)$ : 932.4850; found: 932.4850 .

\section{8. [2]Rotaxane $13-\mathrm{H} \cdot \mathrm{PF}_{6}$}

After evaporating (under reduced pressure) the solvent from a mixture of DB24C8 (69 mg, $0.15 \mathrm{mmol}$ ), the dialkyne $\mathbf{1 0}-\mathrm{H} \cdot \mathrm{PF}_{6}$ (50 $\mathrm{mg}, 0.13 \mathrm{mmol}$ ), and silica gel $(120 \mathrm{mg})$ in $\mathrm{CH}_{3} \mathrm{NO}_{2}(5 \mathrm{~mL})$, the solid obtained was mixed with 3,6-diphenyl-1,2,4,5-tetrazine (180 mg, $0.78 \mathrm{mmol}$ ) and ball-milled at room temperature for $1 \mathrm{~h}$. The resulting solid mixture was transferred to a $5 \mathrm{~mL}$ flask, heated to $100{ }^{\circ} \mathrm{C}$ for 3 days, and then purified chromatographically $\left(\mathrm{SiO}_{2}\right.$ : $\mathrm{MeOH} / \mathrm{CH}_{2} \mathrm{Cl}_{2}, 2: 98$ ) to afford the [2] rotaxane $13-\mathrm{H} \cdot \mathrm{PF}_{6}$ as a white solid (115 mg, 72\%). $\mathrm{Mp}=117-118{ }^{\circ} \mathrm{C} ;{ }^{1} \mathrm{H}$ NMR $\left(400 \mathrm{MHz}, \mathrm{CD}_{3} \mathrm{CN}\right)$ : $\delta=3.50(\mathrm{~s}, 8 \mathrm{H}), 3.68-3.75(\mathrm{~m}, 8 \mathrm{H}), 4.00-4.04(\mathrm{~m}, 8 \mathrm{H}), 4.66(\mathrm{t}, J=6 \mathrm{~Hz}$, $4 \mathrm{H}), 6.79(\mathrm{~s}, 8 \mathrm{H}), 7.12(\mathrm{dd}, J=6,2 \mathrm{~Hz}, 4 \mathrm{H}), 7.27-7.32(\mathrm{~m}, 8 \mathrm{H}), 7.33-7.40$ $(\mathrm{m}, 6 \mathrm{H}), 7.56-7.62(\mathrm{~m}, 6 \mathrm{H}), 7.62-7.70(\mathrm{br}, 2 \mathrm{H}), 7.86(\mathrm{~s}, 2 \mathrm{H}), 8.23$ (dd, $J=8,2 \mathrm{~Hz}, 4 \mathrm{H}) ;{ }^{13} \mathrm{C}$ NMR $\left(100 \mathrm{MHz}, \mathrm{CD}_{3} \mathrm{CN}\right): \delta=53.0,68.9,71.0,71.4$, $113.3,122.1,125.8,127.9,128.9,129.4,129.8,130.2,130.3,130.6,130.9$, 133.1, 136.9, 138.0, 138.4, 139.3, 148.1, 158.3, 159.0; HRMS (ESI): $m / z$ calcd for $[13-\mathrm{H}]^{+}\left(\mathrm{C}_{70} \mathrm{H}_{68} \mathrm{~N}_{5} \mathrm{O}_{8}\right)$ : 1106.5062; found: 1106.5068 .

\section{Acknowledgements}

We thank the National Science Council for financial support (NSC 95-2113-M-002-016-MY3).

\section{Supplementary data}

Spectroscopic data $\left({ }^{1} \mathrm{H}\right.$ and ${ }^{13} \mathrm{C}$ NMR) for all purified [2]rotaxanes. Supplementary data associated with this article can be found in the online version, at doi:10.1016/j.tet.2008.12.082.

\section{References and notes}

1. (a) Molecular Electronics: Science and Technology; Aviram, A., Ratner, M., Eds.; New York Academy of Sciences: New York, NY, 1998; (b) Collier, C. P.; Mattersteig, G.; Wong, E. W.; Luo, Y.; Beverly, K.; Sampaio, J.; Raymo, F. M.; Stoddart, J. F.; Heath, J. R. Science 2000, 289, 1172-1175; (c) Saha, S.; Leung, K. C.-F.; Nguyen, T. D.; Stoddart, J. F.; Zink, J. I. Adv. Funct. Mater. 2007, 17, 685-693; (d) Green, J. E.; Choi, J. W.; Boukai, A.; Bunimovich, Y.; Johnston-Halperin, E.; Delonno, E. Luo, Y.; Sheriff, B. A.; Xu, K.; Shin, Y. S.; Tseng, H.-R.; Stoddart, J. F.; Heath, J. R. Nature 2007, 445, 414-417.

2. For recent examples, see: (a) Alvarez-Perez, M.; Goldup, S. M.; Leigh, D. A; Slawin, A. M. Z. J. Am. Chem. Soc. 2008, 130, 1836-1838; (b) Frey, J.; Tock, C.; Collin, J.-P.; Heitz, V.; Sauvage, J.-P. J. Am. Chem. Soc. 2008, 130, 4592-4593; (c) Zhao, Y.-L.; Dichtel, W. R.; Trabolsi, A.; Saha, S.; Aprahamian, I.; Stoddart, J. F. J. Am. Chem. Soc. 2008, 130, 11294-11296; (d) Chen, N.-C.; Lai, C.-C.; Liu, Y.-H. Peng, S.-M.; Chiu, S.-H. Chem.-Eur. J. 2008, 14, 2904-2908.

3. (a) Ashton, P. R.; Campbell, P. J.; Chrystal, E. J. T.; Glink, P. T.; Menzer, S.; Philp, D.; Spencer, N.; Stoddart, J. F.; Tasker, P. A.; Williams, D. J. Angew, Chem., Int. Ed. Engl. 1995, 34, 1865-1869; (b) Fyfe, M. C. T.; Stoddart, J. F. Adv. Supramol. Chem. 1999, 5, 1-53; (c) Clifford, T.; Abushamleh, A.; Busch, D. H. Proc. Natl. Acad. Sci. U. S.A. 2002, 99, 4830-4836; (d) Badjic, J. D.; Balzani, V.; Credi, A.; Silvi, S.; Stoddart, J. F. Science 2004, 303, 1845-1849; (e) Wu, J.; Leung, K. C.-F.; Benítez, D.; Han, J.-Y.; Cantrill, S. J.; Fang, L.; Stoddart, J. F. Angew. Chem., Int. Ed. 2008, 47, 7470-7474.

4. (a) Orita, A.; Okano, J.; Tawa, Y.; Jiang, L.; Otera, J. Angew. Chem., Int. Ed. 2004, 43 , 3724-3728; (b) Kihara, N.; Hinoue, K.; Takata, T. Macromolecules 2005, 38, 223 226; (c) Liu, R.; Maeda, T.; Kihara, N.; Harada, A.; Takata, T. J. Polym. Sci., Part A: Polym. Chem. 2007, 45, 1571-1574; (d) Hsueh, S.-Y.; Cheng, K.-W.; Lai, C.-C.; Chiu, S.-H. Angew. Chem., Int. Ed. 2008, 47, 4436-4439.

5. Yamawaki, J.; Ando, T. Chem. Lett. 1980, 533-536.

6. After ball-milling the [2]pseudorotaxane formed from dipropargylammonium tetrafluoroborate and $21 \mathrm{C} 7$ on $\mathrm{SiO}_{2}$ with 1,2,4,5-tetrazine, the 'smallest [2]rotaxane' was isolated in $81 \%$ yield; see: Hsu, C.-C.; Chen, N.-C.; Lai, C.-C.; Liu, Y.-H.; Peng, S.-M.; Chiu, S.-H. Angew. Chem., Int. Ed. 2008, 47, 7475-7478.

7. (a) Cheng, P.-N.; Hung, W.-C.; Chiu, S.-H. Tetrahedron Lett. 2005, 46, 4239-4242; (b) Cheng, P.-N.; Huang, P.-Y.; Li, W.-S.; Ueng, S.-H.; Hung, W.-C.; Liu, Y.-H.; Lai, C.-C.; Peng, S.-M.; Chao, I.; Chiu, S.-H. J. Org. Chem. 2006, 71, 2373-2383; (c) Chen, N.-C.; Huang, P.-Y.; Lai, C.-C.; Liu, Y.-H.; Peng, S.-M.; Chiu, S.-H. Chem. Commun. 2007, 4122-4124.

8. For a description of the single-point method, see: (a) Ashton, P. R.; Chrystal, E. J. T.; Glink, P. T.; Menzer, S.; Schiavo, C.; Spencer, N.; Stoddart, J. F.; Tasker, P. A.; White, A. J. P.; Williams, D. J. Chem.-Eur. J. 1996, 2, 709-728; (b) Ashton, P. R.; Fyfe, M. C. T.; Hickingbottom, S. K.; Stoddart, J. F.; White, A. J. P.; Williams, D. J. J. Chem. Soc., Perkin Trans. 2 1998, 2117-2124.

9. We used a similar approach to generate pseudorotaxanes on the surface of silica gel for the efficient synthesis of our 'smallest [2]rotaxane'; see Ref. 6 .

10. A reaction temperature of $373 \mathrm{~K}$ was chosen because (i) the reaction proceeded extremely slowly at temperatures below $353 \mathrm{~K}$ and (ii) significantly lower yields were obtained for the reactions performed at temperatures above $383 \mathrm{~K}$, possibly because of the rapid sublimation of diphenyltetrazine $\mathbf{5}$. 